Egyptian Veterinary Medical Society of Parasitology Journal

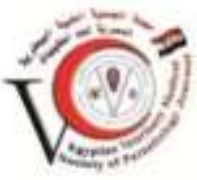

Original Article

\title{
Pharmacokinetics and Bioavailability of cefotaxime in broiler chickens
}

Mohamed El-Hewaity

Department of Pharmacology,

Faculty of Veterinary Medicine,

Menoufia University, Egypt

Corresponding author:

Dr. Mohamed El-Hewaity

E-mail: melhewaty@yahoo.com

\begin{abstract}
:
After a single intravenous (IV) and intramuscular (IM) injection in broiler chickens, the disposition kinetic profile of cefotaxime was explored. Cefotaxime was administered at $10 \mathrm{mg} / \mathrm{kg}$ b.wt dose level for both routes. The serum cefotaxime concentrations estimated at $0.08 \mathrm{~h}$ were $47.06 \mathrm{\mu g} / \mathrm{ml}$ after IV injection, which gradually decreased and cefotaxime was identified up to $12 \mathrm{~h}(0.88 \mu \mathrm{g} / \mathrm{ml})$. In broiler chickens, the average values of $\mathrm{Cl}_{\text {tot }}, \mathrm{Vd}_{\mathrm{ss}}$ and $\mathrm{T}_{0.5 \beta}$ of cefotaxime were $0.09 \mathrm{~L} \mathrm{~kg}^{-1} \mathrm{~h}^{-1}, 0.38 \mathrm{~L} \mathrm{~kg}^{-1}$ and $2.49 \mathrm{~h}$. The highest serum concentration $\left(C_{\max }\right)$ after $\mathrm{IM}$ injection was $(22.21 \pm 2.03 \mu \mathrm{g} / \mathrm{ml})$, the maximum serum concentration period $\left(\mathrm{t}_{\max }\right)$ was $(1.16 \pm 0.11 \mathrm{~h})$ and the half-life of elimination $\left(\mathrm{T}_{0.5 \mathrm{el}}\right)$ was $(3.24 \pm 0.31 \mathrm{~h})$. Bioavailability after IM injection was $84.27 \%$, and in vitro protein binding percent was $28.79 \%$. A recommended IM dosage for cefotaxime in broiler chickens would be $10 \mathrm{mg} / \mathrm{kg}$ b.wt., administered intramuscularly at $12 \mathrm{~h}$ intervals, providing a therapeutic serum concentration in broiler chickens exceeding the MIC $\leq 0.5 \mu \mathrm{g} / \mathrm{ml}$ for most sensitive bacterial pathogens in broiler chickens.
\end{abstract}

Key words: cefotaxime - kinetics- broiler chickens

\section{INTRODUCTION}

Cefotaxime was the primary of the third generation cephalosporins to be free within the market. it's broad spectrum antibiotic and extremely proof against the action of $\beta$ lactamase enzyme. Against gram negative small organisms, it exhibits bigger in vitro activity than any of the previous cephalosporins. it's minimum therapeutic concentration around $0.5 \mu \mathrm{g} / \mathrm{ml}$ for many of the prone micro-organisms (Neu, 1982). Cefotaxime has a very important location in antimicrobial medicine owing to its dilated spectrum of medicament activity, larger resistance to $\beta$-lactamase (Kalager et al., 1982), low nephritic toxicity (Regamy, 1985), wonderful pharmacokinetics characteristics and least downside of microorganism resistance in addition.

Cefotaxime has broad medication spectrum and is principally active against gramnegative bacterium especially on bacteria family together with enterobacteria spp, E. coli, Enterobacter species, Citrobacter freundii, Serratia marcescens, Morganella morganii, and Protus vulgaris. Haemophilus influenza, Neisseria gonorrhoeae and Bacteroides fragilis were liable to this drug. additionally it acts on gram positive bacterium as cocci aureus, non enterococcal streptococci (Jones and Thornsberry, 1982). Cefotaxime is wide used and most prescribed drug because of the antimicrobial spectrum, therapeutic efficaciousness and low adverse impact. (Eidalo et al., 2004).

Pharmacokinetics of cefotaxime have been 130 
studied in sheep (Guerrini et al., 1983), dogs (Guerrini et al., 1986), cats (HcElroy et al., 1986), goats (Atef et al., 1990; Dutta et al., 2004), cattle (Sharma et al., 1995), horses (Orsini et al., 2004) and buffaloes (Sharma et al., 2004; Sharma and Srivastava, 2006). However, there is a little data about cefotaxime disposition kinetics in broiler chicken. Pharmacokinetic studies of antimicrobial agents, which offer a basis for the determination of their satisfactory dose program, are relevant after they are undertaken within the species during which the medication are to be used clinically. The point of this study is to look at the pharmacology of cefotaxime following one IV and IM administration in broiler chickens.

\section{MATERIALS AND METHODS}

\section{Drug:}

Cefotaxime (Cefotax ${ }^{\circledR}$, EIPICO, Egypt, powder equipped for IV or IM injection in strengths equivalent to one $g$ of cefotaxime sodium. The powder was dissolved in distilled water immediately before injection.

\section{Birds:}

Six clearly solid Hubbard broiler chickens of advisement from 1350-1500 $g$ were utilized as an area of this examination. Chickens were nonheritable from a non-public poultry farm, then housed in sanitary floor system and were sustained on adjusted antimicrobial free ration. Water was offered discretionary. before the begin of investigations, chickens were watched for two weeks to make sure that their bodies are free from any antibacterial substances. The investigation was performed as per the foundations set by the moral Committee of Menoufia University, Egypt.

\section{Experimental design:}

'The chickens were one by one weighed before drug injection and also the doses were calculated exactly. The chickens got one IV dose of cefotaxime at a dose of ten $\mathrm{mg} / \mathrm{kg}$ b.wt. After fifteen days a similar chickens got the same dose by IM route (Sharma et al., 2005). About half milliliter of blood was taken from the correct wing vein of every chicken at 5, 10, 15, 20 and $30 \mathrm{~min}$. and at 1, 2, 4, 8, 12 and $24 \mathrm{~h}$ when injection of cefotaxime. All blood samples were collected in sterilized centrifuged tubes and allowed to clot. Serum was separated by activity at 3000 r.p.m for ten minutes. Sera were unbroken frozen till assayed.

\section{Drug bioassay:}

cefotaxime in blood samples was assayed exploitation microbiological methodology of antibiotic using E.coli (ATCC 25922) as a test organism (Arret et al. 1971). Normal curves were made exploitation antibacterial drug free serum collected from chicken and phosphate buffer. Six wells, eight millimeter in diameter, were cut at equal distances in normal Petri dishes containing $25 \mathrm{~mL}$ seeded agar. The wells were stuffed with one hundred $\mu$ l of either the test samples or cefotaxime standards. The plates were unbroken at room temperature for two $h$ before being incubated at 37॰C for eighteen $h$. Zones of inhibition were measured exploitation micrometers, and cefotaxime concentrations in the test samples were calculated from the standard curve. Standard curves of cefotaxime were prepared in antibacterial-free chicken's serum and phosphate buffer by using serial dilution ranging from 0.156 to $50 \mu \mathrm{g} / \mathrm{ml}$. By using a standard curve, serum and tissue concentrations of cefotaxime were determined.

Cefotaxime protein binding was calculated according to (Craig and Suh 1991). This method was depending on the diffusion of free antibiotic into the agar medium. To calculate cefotaxime protein binding, the drug was dissolved 
in phosphate buffer and antibiotic free chicken's serum at different concentrations. This estimation was depending on the facts that free unbound part of cefotaxime only able to diffuse through agar. The differences in the diameters of the inhibition zones between the solutions of the drug in the phosphate buffer and serum samples were then calculated according to the following equation:

Protein binding $\%=$ Zone of inhibition in buffer - Zone of inhibition in serum / Zone of inhibition in buffer $x 100$

\section{Pharmacokinetic analysis:}

Serum concentrations of cefotaxime for each individual chicken after IV and IM administrations were subjected to a compartmental investigation utilizing a nonlinear least-squares regression analysis with the assistance of a computerized curve-stripping program (R Strip; Micromath Scientific Software, Salt Lake City, UT, USA). The appropriate pharmacokinetic model was controlled by visual examination of individual concentration-time curves and by application of Akaike's Information Criterion (AIC) Yamaoka et al. (1978). The pharmacokinetic parameters were reported as mean \pm SD. Information acquired all through the study were investigated utilizing Students t-test (Snedecor and Cochran 1976).

\section{RESULTS}

In the current research, all chickens were definitely healthy during the time of investigation and all medicines were well tolerated. Serum concentrations of $10 \mathrm{mg} /$ $\mathrm{kg}$ b.wt cefotaxime-time profiles after IV and post IM. Expressed in Figure (1). In Table (1), the pharmacokinetic variables corresponding to routes IV and IM were presented. After IV injection of $10 \mathrm{mg}$ cefotaxime / $\mathrm{kg}$, the two open model compartments defined the serum concentration-time information as shown Figure (1). The distributional half-life $\left(T_{0.5}\right.$ a) was fast $(0.52 \mathrm{~h})$. Volume of distribution at steady state (Vdss) was $0.38 \mathrm{~L} \mathrm{~kg}^{-1}$. Results showed that serum cefotaxime concentrations following $\mathrm{IM}$ injection were peaked $22.21 \mu \mathrm{g} / \mathrm{ml}$ at $1.16 \mathrm{~h}$, with elimination half-life $\left(T_{0.5}\right.$ el $)$ of $3.24 \mathrm{~h}$. These results show a better absorption of cefotaxime after IM injection with respective bioavailability of $84.27 \%$. Cefotaxime was bound to plasma protein at a percent 28.79 $\%$.

\section{DISCUSSION}

While cefotaxime was approved in many nations as the first of the third generation cephalosporins, a few pharmacokinetic and pharmacodynamic studies were conducted using this drug. In broiler chickens, the serum concentration-time curves of cefotaxime showed a 2-compartmental course with a rapid serum-to-tissue distribution.

Following IV injection of cefotaxime at a dose of $10 \mathrm{mg} / \mathrm{kg}$ b.wt., serum-to-time levels of cefotaxime stated that cefotaxime pharmacokinetics in broiler chicken was best equipped with the twocompartment open model. The two compartment open model was recorded in ducks for cefotaxime following IV injection (Aboubakr, 2016) and in broiler chicken for cefotaxime after IV injection (Taha and El-bakery, 2017). Elimination half-life for cefotaxime was $2.49 \mathrm{~h}$, Indicating a fast removal of cefotaxime in broiler chicken and agreed with cefotaxime in ducks (1.81 h; Aboubakr, 2016) but shorter than cefotaxime in chickens $(5.15 \mathrm{~h}$; Taha and El-bakery, 2017). Compared with other cephalosporins, cefotaxime elimination half-life in broiler chicken was shorter than ceftiofur in chickens $(4.23 \mathrm{~h}$; Amer et al., 1998). Cefotaxime $\mathrm{Vd}_{\mathrm{ss}}$ in broiler chicken $(0.38 \mathrm{~L} / \mathrm{kg})$, suggesting a 


\section{El-Hewaity,M}

restricted distribution of cefotaxime in broiler chicken that could be ascribed to elevated protein binding activity $(28.79 \%)$. The outcome obtained was almost comparable to that reported in chickens for cefotaxime (0.45 L/kg; Taha and El-bakery, 2017), cefquinome in broiler chickens (0.49 L/kg; Xie et al., 2013) and for cefotaxime in ducks $(0.51 \mathrm{~L} / \mathbf{k g}$; Aboubakr, 2016). In broiler chickens, the total body clearance of cefotaxime was $0.09 \mathrm{I} / \mathrm{kg} / \mathrm{h}$, almost comparable to that reported in chickens for cefotaxime $(0.08 \mathrm{~L} / \mathbf{k g} / \mathbf{h}$; Taha and Elbakery, 2017) and cefotaxime in ducks (0.2 L/kg/h; Aboubakr, 2016) but lower than cefotaxime in sheep $\mathbf{( 0 . 6 5}$ L/kg/h; Guerrini et al., 1983) and calves $(0.81 \mathrm{~L} / \mathrm{kg} / \mathrm{h}$; Sharma et al., 1995). The absorption half-life was $(0.27 \mathrm{~h})$ after IM injection of cefotaxime in broiler chichens. This was lower than the value reported in chickens for cefotaxime (0.62 h; Taha and Elbakery, 2017). Half-life elimination was (3.24 h) almost comparable in chickens to cefotaxime (4.03 h; Taha and Elbakery, 2017). While it longer than cefotaxime in ducks (1.77 $\mathrm{h}$; Aboubakr, 2016). After IM administration, the largest mean concentration of cefotaxime identified in chicken serum was $22.21 \mu \mathrm{g} / \mathrm{ml}$ at $1.16 \mathrm{~h}\left(\mathrm{~T}_{\max }\right)$.

The results were almost comparable to those reported in chickens for cefotaxim e $(25.02 \mu \mathrm{g} / \mathrm{ml}$ at $1.08 \mathrm{~h}$; Taha and $\mathrm{E}$ Ibakery, 2017) and greater than cefotax ime in ducks (14.72 $\mu \mathrm{g} / \mathrm{ml}$; Aboubakr , 2016) and cefquinome $(9.38 \mu \mathrm{g} / \mathrm{ml}$ at $0.38 \mathrm{~h}$ ) in ducks (Yuan et al., 2011). In this research, bioavailability of Cefotaxime was 84.27 percent. This value referred to excellent intramuscular administration absorption from its site. This research is consistent with that reported in chickens for cefotaxime (85.11 percent; Taha and Elbakery, 2017) and duck cefotaxime (79.61 percent; Aboubakr, 2016) but lower than duck cefquinome $\mathbf{( 9 3 . 2 8}$ percent; Yuan et al., 2011).

In drug therapy, binding to serum proteins plays a significant role as the non-proteinbound portion of a drug in serum can penetrate and balance with the additional vascular room (Bergogne-Berezin, 2002). For antimicrobial therapy, penetration into the additional vascular space is very essential, as most bacterial and fungal infections happen in tissue interstitial fluid or other body fluids other than blood (Wise, 1983). In this research, it was discovered that the ability of cefotaxime to interact with chicken serum proteins was (28.79\%) and this outcome was agreed with that reported by Aboubakr (2016), who discovered that the proportion of cefotaxime protein binding was $31.48 \%$.

The primary objective of this research was to determine adequate dosage regimen of cefotaxime in broiler chickens to be clinically used to treat various mild to serious bacterial diseases efficiently. It was reported that cefotaxime's minimum inhibitory concentration (MIC90) was 0.016-1 $\mathrm{\mu g} / \mathrm{ml}$ (Knudsen et al., 1997). Using a MIC of cefotaxime as $0.5 \mu \mathrm{g} / \mathrm{ml}$, serum drug levels should reach at least 40 percent to 50 percent of causative bacteria MIC for time-dependent bacteria during the dose interval (Levison and Levison, 2009). Using a cefotaxime MIC of $0.5 \mu \mathrm{g} / \mathrm{ml}$, concentrations above 0.5 $\mu \mathrm{g} / \mathrm{mL}$ were observed in all birds up to $12 \mathrm{~h}$ following administration in our research. So the suitable dosage regimen of cefotaxime in chicken should be 10 $\mathrm{mg} / \mathrm{kg}$ intramuscular at $12 \mathrm{~h}$ intervals.

\section{Conclusion}


It is reasoned that administration of cefotaxime is very useful in treatment of different bacterial infections in broiler chickens with MIC $\leq 0.5 \mu \mathrm{g} / \mathrm{ml}$ and the recommended dose is $10 \mathrm{mg} / \mathrm{kg}$ bwt given by IM route at $12 \mathrm{~h}$ intervals.

\section{Conflict of Interests}

The author declares that there is no conflict of interests regarding the publication of this article 
Table 1: Mean \pm SE serum pharmacokinetic parameters of cefotaxime in broiler chicken following a Single IV and IM administration of $10 \mathrm{mg} / \mathrm{kg}$ b.wt. $(\mathrm{n}=6)$.

\begin{tabular}{|c|c|c|c|}
\hline PARAMETER & UNIT & IV & IM \\
\hline$\alpha\left(K_{a b}\right)$ & $h^{-1}$ & $1.35 \pm 0.14$ & $2.58 \pm 0.27$ \\
\hline$T_{0.5 \alpha}\left(T_{0.5 \mathrm{ab}}\right)$ & $\mathbf{h}$ & $0.52 \pm 0.09$ & $0.27 \pm 0.05$ \\
\hline$\beta\left(\mathbf{K}_{\mathrm{el}}\right)$ & $h^{-1}$ & $0.28 \pm 0.06$ & $0.21 \pm 0.02$ \\
\hline$T_{0.5 \beta}\left(T_{0.5 \mathrm{el}}\right)$ & h & $2.49 \pm 0.23$ & $3.24 \pm 0.31$ \\
\hline Vc & $\mathrm{L} \mathrm{kg}^{-1}$ & $0.21 \pm 0.03$ & --- \\
\hline$\overline{V d_{s s}}$ & $\mathrm{~L} \mathrm{~kg}^{-1}$ & $0.38 \pm 0.05$ & -- \\
\hline $\mathbf{V} \mathbf{d}_{(\text {area })}$ & $\mathrm{L} \mathrm{kg}^{-1}$ & $0.32 \pm 0.02$ & --- \\
\hline$K_{12}$ & $h^{-1}$ & $0.77 \pm 0.12$ & --- \\
\hline $\mathbf{K}_{21}$ & $h^{-1}$ & $0.85 \pm 0.10$ & --- \\
\hline $\mathrm{Cl}_{\text {tot }}$ & $\mathrm{L} \mathrm{kg}^{-1} \mathrm{~h}^{-1}$ & $0.09 \pm 0.008$ & --- \\
\hline $\mathrm{C}_{\max }$ & $\mu \mathrm{g} \cdot \mathrm{ml}^{-1}$ & --- & $22.21 \pm 2.03$ \\
\hline $\mathbf{T}_{\max }$ & h & $-\cdots$ & $1.16 \pm 0.11$ \\
\hline $\mathbf{A U C}$ & 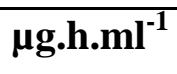 & $118.42 \pm 11.23$ & $99.79 \pm 7.14$ \\
\hline MRT & $\mathbf{h}$ & $2.77 \pm 0.29$ & $3.98 \pm 0.41$ \\
\hline $\mathbf{F}$ & $\%$ & & $84.27 \pm 3.56$ \\
\hline
\end{tabular}

$\mathrm{K}_{\mathrm{ab}}$ : First-order absorption rate constant; $\mathrm{T}_{0.5(\mathrm{ab})}$ : Absorption half-life; $\mathrm{K}_{\mathrm{el}}$ : First-order elimination rate constant; $\mathrm{T}_{0.5(\mathrm{el})}$ : Elimination half-life; $\mathrm{C}_{\max }$ : Maximum serum concentration; $\mathrm{T}_{\max }$ : Time to peak serum concentration; $\mathrm{AUC}_{(0 \text {-inf) }}$ : Area under serum concentration-time curve; MRT: Mean residence time; $F$ fraction of drug absorbed systemically after IM injection. $T^{1} 1 / 2(\alpha)$ : Distribution half-life; Vc: Apparent volume of central compartment; $\mathrm{Vd}(\mathrm{area})$ : Apparent volume of distribution calculated by area method ; Vdss: Volume of distribution at steady state; K12 : First-order constant for transfer from central to peripheral compartment; K21: First-order constant for transfer from peripheral to central compartment; Kel: Elimination rate constant; $\mathrm{T}^{1} / 2(\beta)$ : Elimination half-life; $A U C(0-i n f)$ : Area under serum concentration-time curve; MRT: Mean residence time; Cltot: Total body clearance. 
Figure 1. Semi-logarithmic graph depicting the time course of cefotaxime in broilers after a single IV and IM administration of $10 \mathrm{mg} / \mathrm{kg} \cdot \mathrm{b} . w \mathrm{t} .(\mathrm{n}=6)$.

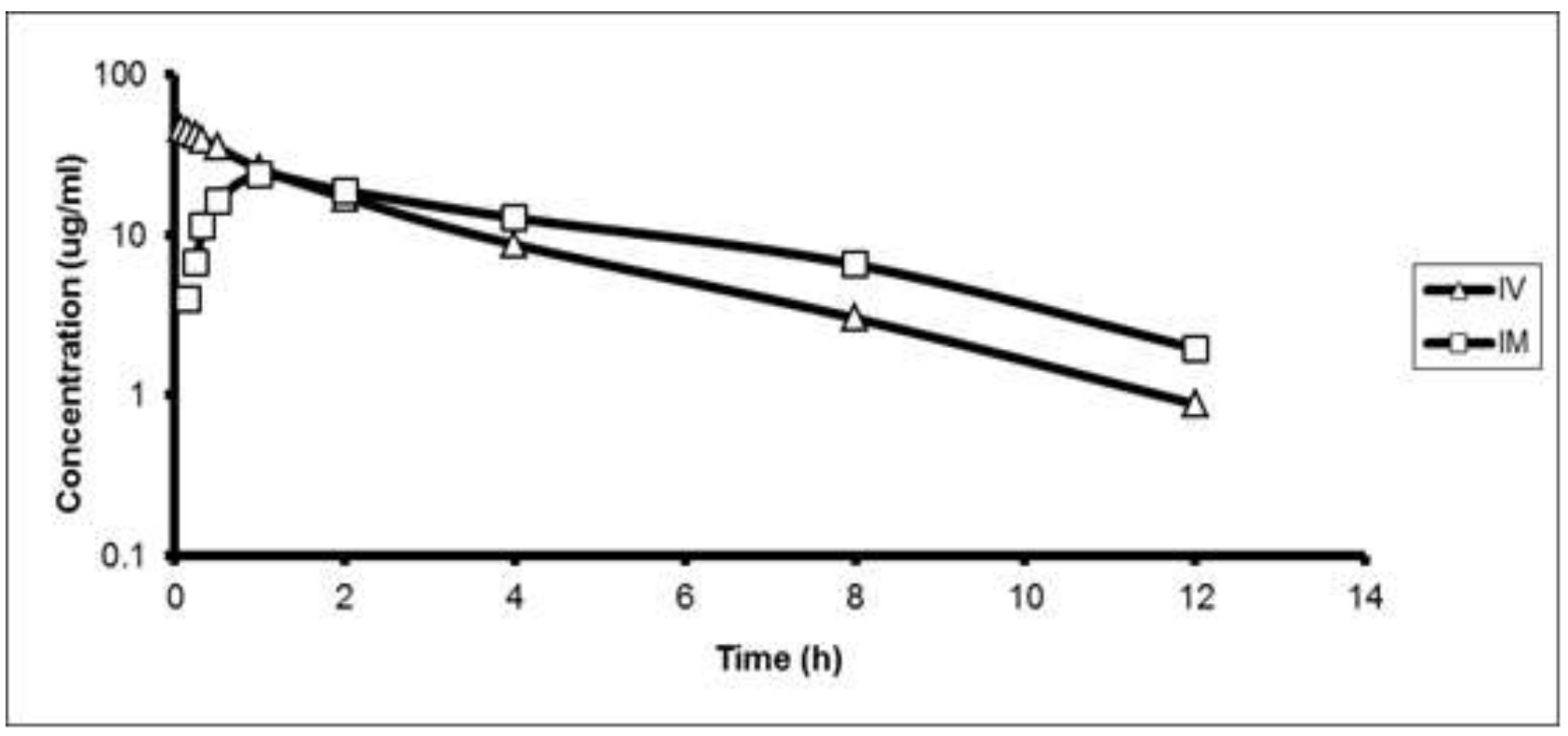




\section{REFERENCES}

Aboubakr, M. (2016): Bioavailability and pharmacokinetics of cefotaxime in Muscovy ducks. International Journal of Pharmacology and Toxicology. 4 (1): 9395.

Amer, AM. Fahim, EM. And Ibrahim, RK. (1998): Effect of aflatoxicosis on the kinetic behaviour of ceftiofur in chickens. Res Vet Sci. 65 (2):115-118.

Arret, B., Johnson, D. and Kirshboum, A. (1971): Outline of details for microbiological assay of antibiotics, second revision. Pharmacology Science. 60, 1689-1694.

Atef, M. Ramadan, A. Afifi, NA. and Youssef, S. (1990): Pharmacokinetic profile of cefotaxime in goats. Res Vet Sci. 49: 34 -38.

Bergogne-Berezin, E. (2002): Clinical role of protein binding of quinolones. Clinical Pharmacokinetic 41: 741-750.

Brander, G.C., Pugh, D.M., Baywater, R.J. and Jenkins, W.L. (1991): Veterinary Applied Pharmacology and Therapeutics. Fifth Ed. The English language Book Society and Boilliere, Trindall, London.

Craig, A.W. and Suh, B. (1980): Protein binding and the antibacterial effects. Method for the determination of protein binding, in: LORIAN, V. (Ed.) Antibiotics in Laboratory Medicine, 3rd edn, (Baltimore, Maryland, USA, Williams \& Wilkins) pp. 367- 402.

Dutta, BP. Debnathm, SC. Mandal, TK. and Chakraborty, AK. (2004): Modification of pharmacokinetics of cefotaxime in uranyl nitrate-induced renal damage in black bengal goats. J Vet Sci. 5: 1-3.

Eidalo, AS. Ali, AS. Shadded, SI. and Mohamed, AH. (2004): Pharmacokinetics study of cefixime in sheep and cattle. J. Anim.Vet. Adv. 3(1): 36-38.
Guerrini, VH. English, PB. Filippich, LJ. Schneider, J. and Bourne, DWA. (1986): Pharmacokinetics of cefotaxime in the dog. Vet Rec. 119: 81-83.

Guerrini, VH., Filippich LJ. English, PB. and Bourne, DWA. (1983): Pharmacokinetics of Cefotaxime in sheep. Am J Vet Res. 44: 1488-1491.

Kalager, T. Digranes, A. Bakke, K. Hellum, KB. Bergan, T. and Solberg, C. (1982): Cefotaxime in serious infections: A clinical and pharmaco-kinetic study. J Antimicrob Chemother. 9: 157-163.

Knudsen, JD., Fuursted, K., Frimodt-Moller, N. and Espersenm F. (1997): Comparison of the effect of cefepime with four cephalosporins against pneumococci with various susceptibilities to penicillin, in vitro and in mouse peritonitis model. J Antimicrob Chemother. 40: 679-686.

Levison, M.E. and Levison, J.H. (2009): Pharmacokinetics and pharmacodynamics of anti-bacterial agents. Infect. Dis. Clin. North Am. ;23: 791-815.

McElroy, D. Ravis, WR. and Clark, CH. (1986): Pharmacokinetics of cefo-taxime in the domestic cat. Am J Vet Res. 47: 86-88.

Neu, HC. (1982): The in vitro activity, human pharmacology, and clinical effectiveness of new beta-lactam antibiotics. Annu Rev Pharmacol Toxicol. 22, 599-642.

Orsini, JA. Moate, PJ. Engiles, J. Norman, T. Poppenga, R. Benson, CE. and Boston, RC. (2004): Cefotaxime kinetics in plasma and synovial fluid following intravenous administration in horses. $J$ Vet Pharmacol Ther. 27(5): 293-298.

Regamy, C. (1985). Pharmacokinetic of ceftriaxone and its relation to concentration in extravascular compartments, comparison with cefotaxime. Chemotherapy. 31: 85-94.

Sharma, SK. and Srivastava, AK. (2006): subcutaneous pharmacokinetics and dosage 
regimen of cefotaxime in buffalo calves (Bubalus buba-lis). J Vet Sci. 7(2): 119-

22.

Sharma, SK. Srivastava, AK. and Bal, MS. (1995): Disposition kinetics and dosage regimen of cefotaxime in crossbred male calves. Vet Res. 26: 168-173.

Sharma, SK. Srivastava, AK. and Deore, MD. (2004): Pharmacokinetic disposition of cefotaxime in buffalo calves (Bubalus bubalis) following single intramuscular administration. Indian J Anim Sci. 74: 590593.

Snedecor, G.W. and Cochran, T. (1976): "Statistical Methods" 6th ed. pp. Ames, lowa U.S.A., 502-503.

Taha, H.S. and El-bakery, Z. (2017): Animal Health Research Journal Vol. 5, No. 1, 107-115.

Wise, R. (1983): Protein binding of betalactams: the effects on activity and pharma-cology particularly tissue penetration. II.Studies in man. J. Antimicrob. Chemo-Ther.,12: 105-118

Xie, W. Zhang, X. Wang, T. and Du, S. (2013): Pharmacokinetic analysis of cefquinome in healthy chickens. Br Poult Sci. 54(1): 81-86.

Yamaoka, K., Nakagawa, T. and Uno, T. (1978): Statistical moment in pharmacokinetics. Journal of Pharmacokinetic and Biopharmaceutics, 6, 547-558.

Yuan, L. Sun, J. Wang, R. Sun, L. Zhu, L. Luo, X. Fang, B. and Liu, Y. (2011): Pharmacokinetics and bioavailability of cefquinome in healthy ducks. Am $\mathrm{J}$ Vet Res. 72(1): 122-126. 


$$
\text { الملخص العربي }
$$

المسار الحركي والاتاحة الحيوية للسيفوتاكسيم في دجاج التسمين

$$
\text { قسم الادويةـ كلية الطب البيطري- جامعة المنوفية }
$$

استهدفت هذه الدر اسة تقييم المسار الحركي والاتاحة الحيوية للسيفوتاكسيم (• ( مجم / كجم) بعد الحقن الوريدي و العضلي في دجاج التسمين. تم تحديد تركيزات السيفوتاكسيم في مصل الدم بواسطة تقنية الفحص الميكروبيولوجي باستخدام (E.coli ATCC 25922) و أوضحت النتائج بعد الحقن الوريدي استمرار تواجد السيفوتاكسيم في المصل لمدة Y I ساعة بعد الحقن وكان التركيز 0.88 ميكروجر ام لكل ملي. واظهرت النتائج بعد الحقن العضلي تسجيل اعلي تركيز للسيفوتاكسيم في المصل عند 1.16 ساعة ومعدل النصف للاخر اج كان

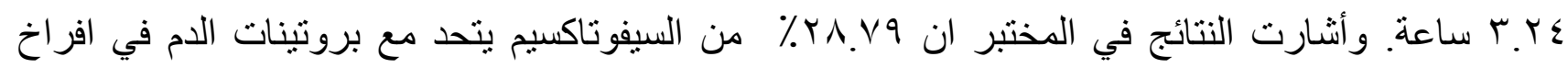

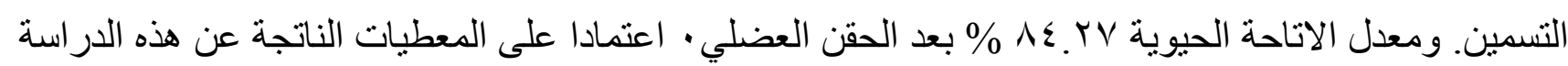
وجد انه عند اعطاء السيفوتاكسيم بجرعة • ( مجم / كجم فى الوريد او العضل انه سريع الامتصاص مع زيادة

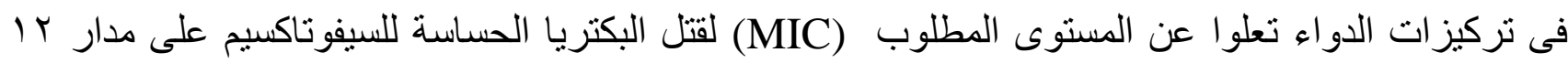
ساعة بعد الحقن في دجاج التسمين. 